\title{
Antitumor Activity of Methanol Extract from Roots of Agrimonia pilosa LEDEB.
}

\author{
Ryozo KOSHIURA, Kenichi MIYAMOTO, Yukinobu IKEYA* and \\ Heihachiro TAGUCHI* \\ Department of Pharmacology. Hokuriku University School of Pharmacy. \\ Ho-3 Kanagawa-machi, Kanazawa 920-11, Japan \\ *Tsumura Laboratory, Izumi-honcho, Komae. Tokyo 201, Japan
}

Accepted January 18,1985

\begin{abstract}
To evaluate the antitumor activity of Agrimonia pilosa LEDEB., the effects of the methanol extract from roots of the plant (AP-M) on several transplantable rodent tumors were investigated. AP-M significantly prolonged the life span of S180-, Meth-A fibrosarcoma- and MM-2 mammary carcinoma-bearing mice by intraperitoneal (i.p.) pre- or postmedication. AP-M also inhibited the growth of S-180 solid type tumor. On the other hand, the prolongation of life span induced by AP-M on S-180 ascites type tumor-bearing mice was markedly minimized or abolished by the pretreatment of cyclophosphamide. AP-M showed considerably strong cytotoxicity on MM-2 cells in vitro, but the effect was diminished to one-tenth by the addition of serum to the culture. Against the host animals, the peripheral white blood cells in mice were significantly increased from 2 to 5 days after the i.p. injection of AP-M. On 4th day after the injection of AP-M, the peritoneal exudate cells which possessed the cytotoxic activity on MM-2 cells in vitro were also increased to about 5 -fold those in the non-treated control. The spleen of the mice was enlarged, and the spleen cells possessed the capacity to uptake ${ }^{3} \mathrm{H}$ thymidine. However. AP-M did not show direct migration activity like other mitogens against spleen cells from non-treated mice. These results indicate that the roots of Agrimonia pilosa contain some antitumor constituents, and possible mechanisms of the antitumor activity may be some host-mediated actions and direct cytotoxicity.
\end{abstract}

Agrimonia pilosa LEDEB. (Rosaceae, Japanese name: Kinmizuhiki) has been used as an antidiarrheic, a hemostatic and an antiparasitic in Japan and China (1,2). Furthermore, we saw a description about the effectiveness of the plant on some carcinomas in Ben-cao-gang-mu (3), and the plant is being used for cancer therapy in China today (4). However, there are only a few reports describing fundamental experiments on the antitumor activity of this plant $(5,6)$.

In the present study, we investigated the antitumor activity of the methanol extract from roots of Agrimonia pilosa LEDEB. against some transplantable rodent tumors.

\begin{abstract}
Materials and Methods
Animals and tumors

Female 6-weeks-old ddY, BALB/C and $\mathrm{C} 3 \mathrm{H} / \mathrm{He}$ mice were purchased from Shizuoka Laboratory Animal Center, Hamamatsu. S180. Meth-A fibrosarcoma and MM-2. mammary carcinoma were maintained by intraperitoneal (i.p.) passage at weekly intervals in ddY, BALB/C and $\mathrm{C} 3 \mathrm{H} / \mathrm{He}$ mice, respectively.
\end{abstract}

Preparation of the methanol extract

The roots of $A$. pilosa growing wildly around this university were collected in early autumn. The roots $(800 \mathrm{~g})$ were dried and powdered and then extracted three-times 
with $4.5 \mathrm{I}$ of methanol in reflux. The methanol solution was cooled, filtered and dried in vacuo to give a brown residue (AP-M. $139.7 \mathrm{~g}$ ). AP-M was dissolved or suspended in phosphate-buffered saline (PBS) immediately before use.

\section{Agents}

OK-432 (Chugai), cyclophosphamide (CPA, Shionogi) and concanavalin A (Con A. Maruzen Oil) were commercially purchased. Klebsiella 03 lipopolysaccharide KO3 LPS) was prepared from the culture supernatant of decapsulated mutant strain LEN-1 (03: $\mathrm{K}^{-}$) derived from $K$. pneumoniae strain Kasuya as described previously (7).

\section{Antitumor experiments in mice}

To evaluate the antitumor activities against ascites type tumors, mice were i.p. inoculated with tumor cells $\left(1 \times 10^{5}\right.$ or $10^{6} \mathrm{~S}-180$ cells $/$ ddY mouse, $1 \times 10^{b}$ Meth-A cells /BALB/C mouse. $5 \times 10^{5} \mathrm{MM}-2$ cells $/ \mathrm{C} 3 \mathrm{H} / \mathrm{He}$ mouse) on day 0 according to the treatment schedules indicated in the tables. Sixty days after the cell inoculation. survivors were killed and autopsied. For S-180 solid type tumor, mice were subcutaneously (s.c.) inoculated at the left inguinal region with $3 \times 10^{6}$ tumor cells on day 0 and were i.p. medicated on days 1 to 12. Thirty-six days after the cell inoculation. the tumors were removed and weighed.

Assay of direct cytotoxic activity against MM-2 cells

A $2 \mathrm{ml}$ aliquot of tumor cells $\left(2 \times 10^{5}\right.$ ceils $/ \mathrm{ml}$ ) prepared in RPMI 1640 medium with or without $10 \%$ fetal calf serum was added with graded concentrations of AP-M and was incubated at $37^{\circ} \mathrm{C}$ for $2 \mathrm{hr}$. Then, cells were washed with Hanks' solution and were further incubated in RPMI 1640 medium supplemented with $10 \%$ fetal calf serum and $10 \mu \mathrm{M}$ mercaptoethanol at $37^{\circ} \mathrm{C}$ in a humidified $\mathrm{CO}_{2}$ incubator for $48 \mathrm{hr}$. The viable cells were assayed by a dye exclusion method with $0.2 \%$ Trypan Blue.

Assay of number and population of peripheral white blood cell (WBC)

The peripheral blood was obtained from the mice treated with AP-M by the ocular fundus puncture. Total WBC number was estimated by using a Bürker-Türk hemocytometer. For the determination of the cell population, cells were stained with Giemsa stain, and about 400 nucleated cells were counted for each slide glass.

Harvesting of peritoneal exudate cell (PEC) and cytotoxicity of adherent PEC

PECs were collected from the mouse 4 days after i.p. injection of AP-M or OK-432 by washing the peritoneal cavity with $3 \mathrm{ml}$ of Hanks' solution and were washed 3 times with RPMI 1640 medium. The cell number was estimated by the standard hemocytometer technique. PECs $\left(5 \times 10^{6}\right.$ cells $)$ suspended in RPMI 1640 medium supplemented with $10 \%$ fetal calf serum and $10 \mu \mathrm{M}$ mercaptoethanol were placed on a $35-\mathrm{mm}$ plastic petri dish and were cultured for $1 \mathrm{hr}$. The dish was washed to remove non-adherent cells. Then, a $2 \mathrm{ml}$ aliquot of MM-2 cells $\left(5 \times 10^{5}\right.$ cells) suspended in the culture medium was added to the dish and was cultured for $40 \mathrm{hr}$ at $37^{\circ} \mathrm{C}$. After the culture, the viable MM-2 cells were counted by the Trypan Blue dye exclusion method.

\section{Experiments of ${ }^{3} \mathrm{H}$-thymidine ( $\mathrm{TdR}$ ) uptake by spleen cells}

1) ${ }^{3} \mathrm{H}-\mathrm{TdR}$ uptake by spleen cells from the mice treated with AP-M or OK-432: $A$ single cell suspension was prepared from the spleen of the mouse treated with each agent by the standard technique. A one $\mathrm{ml}$ aliquot of the cell suspension $\left(1 \times 10^{6}\right.$ cells/ $\mathrm{ml}$ of RPMI 1640 medium supplemented with $10 \%$ fetal calf serum and $10 \mu \mathrm{M}$ mercaptoethanol) was incubated for $1 \mathrm{hr}$ and was further incubated with $1.0 / 2 \mathrm{Ci}{ }^{3} \mathrm{H}-\mathrm{TdR}$ for $24 \mathrm{hr}$ at $37^{\circ} \mathrm{C}$.

2) ${ }^{3} \mathrm{H}-\mathrm{TdR}$ uptake by spleen cells treated with $A P-M$ or mitogens in vitro: $A$ one $\mathrm{ml}$ aliquot of the cell suspension $\left(1 \times 10^{6}\right.$ cells) prepared from non-treated mice spleen was incubated with AP-M or a mitogen for $24 \mathrm{hr}$ at $37^{\circ} \mathrm{C}$. Then, $1.0 \mu \mathrm{Ci}{ }^{3} \mathrm{H}-\mathrm{TdR}$ was added to the culture medium, and the culture was further incubated for $24 \mathrm{hr}$.

After the incubation, cells were harvested on a glass fiber filter (Whatman, GF/C) and then washed with cold PBS, 5\% trichloroacetic acid and an ethanol:ether $(3: 1, v / v)$ mixture. The radioactivity on the filter was counted in a toluene-based scintillator (PPO $4 \mathrm{~g}$. POPOP $0.1 \mathrm{~g}$, toluene $1 \mathrm{l}$ ) by a Beckman LS-230 liquid scintillation counter. 


\section{Results}

Antitumor activity of AP-M against S-180 in mice: When AP-M Was i.p. given to ddY mice i.p. inoculated with $1 \times 10^{5}$ cells on day 0 , the extract significantly prolonged the life span of the mice bearing $\mathrm{S}-180$ in each of the medication schedules (Table 1). Even when AP-M was given by a single injection 14 days before the tumor inoculation, a marked tumor growth suppression was observed. Among these medication schedules, a single administration of AP-M on day -4 or on day +1 appeared to be more effective. Table 2 shows the results of the experiments of the activity of AP-M against the mice i.p. inoculated with a large inoculum of the tumor cells $\left(1 \times 10^{6}\right.$ cells), and it shows the influence of CPA on the antitumor activity of the extract. The antitumor activity of AP-M was observed clearly, but it was lower than that against the mice inoculated with $1 \times 10^{5}$ cells. CPA (40 $\mathrm{mg} / \mathrm{kg}$ ) was i.p. injected once a day on days -6 to -2 . The prolongation of life span induced by AP-M was cancelled or minimized by CPA, while CPA alone hardly influenced the survival time of the mice bearing S-180 ascites tumor.

Next, the antitumor activity of AP-M against solid type tumor was examined. Mice were s.c. inoculated with $3 \times 10^{6}$ cells and were given AP-M i.p., once a day for 12 days from $24 \mathrm{hr}$ after the cell inoculation. As shown in Fig. 1 and Table 3.3 and $10 \mathrm{mg} / \mathrm{kg}$ of AP-M

Table 1. Antitumor activity of AP-M against S-180 ascites type tumor

\begin{tabular}{lcccc}
\hline $\begin{array}{l}\text { Medication } \\
\text { schedule }\end{array}$ & $\begin{array}{c}\text { Single dose } \\
(\mathrm{mg} / \mathrm{kg})\end{array}$ & $\begin{array}{c}\text { Survival daysa } \\
\text { (mean } \pm \text { S.E.) }\end{array}$ & \%ILS & $\begin{array}{c}60 \text {-day } \\
\text { survivors }\end{array}$ \\
on days $-7 \sim-1$ & 10 & $28.3 \pm 3.7$ & 146 & 3 \\
on day -14 & 100 & $26.5 \pm 6.6$ & 130 & 2 \\
on day -7 & 100 & $26.2 \pm 4.0$ & 128 & 1 \\
on day -4 & 100 & $31.7 \pm 7.4$ & 176 & 3 \\
on day -1 & 100 & $26.5 \pm 3.0$ & 130 & 2 \\
on day +1 & 100 & 34 & 196 & 5 \\
on day +4 & 100 & $20.0 \pm 2.9$ & 74 & 2 \\
on day +7 & 100 & $14.3 \pm 2.9$ & 24 & 3 \\
on days $+1,4.7$ & 100 & $34.5 \pm 5.1$ & 200 & 2 \\
on days $+1 \sim+7$ & 10 & $36.3 \pm 3.3$ & 216 & 2 \\
\hline
\end{tabular}

Six ddY mice were i.p. inoculated with $1 \times 10^{5}$ cells on day 0 and were i.p. administered with AP-M once a day according to the indicated schedule. The mean survival time of non-treated control mice was 11.5 days. "Excluding 60-day survivors. " $[(\mathrm{T}-\mathrm{C}) / \mathrm{C}] \times 100$. T: mean survival days of treated mice. $C$ : mean survival days of non-treated control mice. "Macroscopic tumor findings were negative.

Table 2. Pretreatment effect of CPA on the antitumor activity of AP-M against S-180 ascites type tumor

\begin{tabular}{|c|c|c|c|c|c|c|c|}
\hline \multirow[t]{2}{*}{$\begin{array}{l}\text { Medication } \\
\text { schedule }\end{array}$} & \multirow[t]{2}{*}{$\begin{array}{c}\text { Single dose } \\
(\mathrm{mg} / \mathrm{kg})\end{array}$} & \multicolumn{2}{|c|}{$\begin{array}{c}\text { Survival days: } \\
\text { (mean } \pm \text { S.E.) }\end{array}$} & \multicolumn{2}{|c|}{$\%$ ILS } & \multicolumn{2}{|c|}{$\begin{array}{l}60 \text {-day } \\
\text { survivorse }\end{array}$} \\
\hline & & $\begin{array}{c}\text { without CPA } \\
\text { (A) }\end{array}$ & with CPA & $(\mathrm{A})$ & (B) & $(A)$ & (B) \\
\hline \multirow[t]{2}{*}{ on day -4} & 100 & $23.3 \pm 2.6$ & $16.6 \pm 2.5$ & 130 & 64 & 1 & 0 \\
\hline & 100 & $16.6 \pm 1.0$ & $7.0 \pm 0.0$ & 64 & -31 & 0 & 0 \\
\hline \multirow[t]{2}{*}{ on days $+1 \sim+7$} & 30 & $21.4 \pm 2.9$ & $7.3 \pm 0.3$ & 112 & -28 & 0 & 0 \\
\hline & 10 & $14.0 \pm 2.3$ & $7.6 \pm 1.2$ & 39 & -25 & 0 & 0 \\
\hline
\end{tabular}

Six mice were i.p. inoculated with $1 \times 10^{6}$ cells on day 0 and were i.p. administered with AP-M once a day according to the indicated schedule. CPA $(40 \mathrm{mg} / \mathrm{kg})$ was i.p. given once a day on days -6 to -2 . The mean survival time of non-treated control mice and CPA-pretreated mice was 10.1 days and 9.4 days. respectively. at Excluding 60-day survivors. "Described in footnote b of Table 1. c Macroscopic tumor findings were negative. 
significantly suppressed the tumor growth.

Antitumor activity of AP-M against Meth$A$ ascites type tumor: BALB/C mice were i.p. inoculated with $1 \times 10^{5}$ Meth-A fibrosarcoma cells on day $O$ and AP-M was i.p. administered once a day on days -7 to -2 as the premedication or on days +1 to +7 as the postmedication. AP-M also prolonged the life span of the mice. The premedication of 10 $\mathrm{mg} / \mathrm{kg}$ of the extract was most effective (Table 4).

Antitumor activity of AP-M against MM-2 ascites type tumor: The antitumor activity of $A P-M$ against the mice bearing $M M-2$ was compared with that of OK-432 (Table 5). $\mathrm{C} 3 \mathrm{H} / \mathrm{He}$ mice were i.p. inoculated with $5 \times 10^{5}$ cells on day 0. AP-M was i.p. administered once on day -4 as the premedication because the activity of the extract against S-180 ascites type tumor was most effective when the extract was administered this day (Table 1). For the postmedication. AP-M was i.p. administered 3 times on days $+1,+4$ and

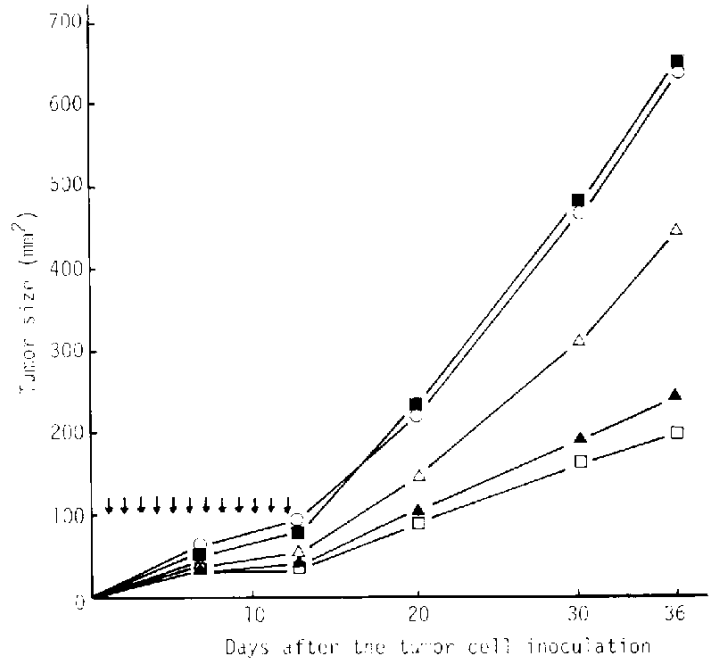

Fig. 1. Effect of AP-M on the growth of S-180 solid type tumor. Ten ddY mice were s.c. inoculated with $3 \times 10^{6}$ cells/mouse on day O. AP-M was i.p. administered at arrows at doses of $30(\Delta), 10(\div)$. $3.0(\mathbf{\Delta}), 1.0(\boldsymbol{D})$ and $0 \mathrm{mg} / \mathrm{kg}$ (control, $\mathrm{O})$.

Table 3. Antitumor activity of AP-M against S-180 solid type tumor

\begin{tabular}{ccc}
$\begin{array}{c}\text { Single dose } \\
(\mathrm{mg} / \mathrm{kg})\end{array}$ & $\begin{array}{c}\text { Tumor weight } \\
(\mathrm{g}) \\
(\operatorname{mean} \pm \mathrm{S} . \mathrm{E} .)\end{array}$ & $\begin{array}{c}\text { \% of } \\
\text { inhibition }\end{array}$ \\
30 & $4.92 \pm 1.40$ & 36.4 \\
10 & $1.77 \pm 0.57$ & 77.1 \\
3 & $2.29 \pm 0.63$ & 70.4 \\
1 & $7.46=2.11$ & 3.6 \\
0 & $7.75 \pm 0.94$ & - \\
\hline
\end{tabular}

Ten ddY mice were s.c. inoculated with $3 \times 10^{6}$ ceils on day 0 and were i.p. administered with AP-M once a day for 12 days. "Wet weight 36 days after the cell inoculation. "[(C-T)/T] $\times 100, T$ : mean weight of tumor in the test group, C: mean weight of tumor in the control group.

Table 4. Antitumor activity of AP-M against Meth-A ascites type tumor

\begin{tabular}{|c|c|c|c|c|}
\hline $\begin{array}{l}\text { Medication } \\
\text { schedule }\end{array}$ & $\begin{array}{c}\text { Single dose } \\
(\mathrm{mg} / \mathrm{kg})\end{array}$ & $\begin{array}{l}\text { Survival daysia } \\
\text { (mean } \pm S . E .)\end{array}$ & $\% \mid L S^{\prime}$ & $\begin{array}{l}\text { 60-day } \\
\text { survivors }\end{array}$ \\
\hline \multirow[t]{4}{*}{ on days $-7 \sim-2$} & 30 & $14.3 \pm 1.6$ & -6 & 0 \\
\hline & 10 & $32.7 \pm 5.0$ & 115 & 2 \\
\hline & 3 & $20.3 \pm 1.9$ & 34 & 0 \\
\hline & 1 & $16.5 \pm 1.0$ & 9 & 0 \\
\hline \multirow[t]{4}{*}{ on days $+1 \sim+7$} & 30 & $23.0 \pm 0.8$ & 51 & 0 \\
\hline & 10 & $20.5 \pm 1.1$ & 35 & 0 \\
\hline & 3 & $19.5 \pm 0.7$ & 28 & 0 \\
\hline & 1 & $20.5 \pm 1.0$ & 35 & 0 \\
\hline
\end{tabular}

Six BALB/c mice were i.p. inoculated with $1 \times 10^{5}$ cells on day 0 and were i.p. administered with $A P-M$ once a day according to the indicated schedule. The mean survival time of non-treated control mice was 15.2 days. "Excluding 60-day survivors. "Described in footnote b of Table 1. CMacroscopic tumor findings were negative. 
Table 5. Antitumor activity of $A P-M$ and $O K-432$ against MM-2 ascites type tumor

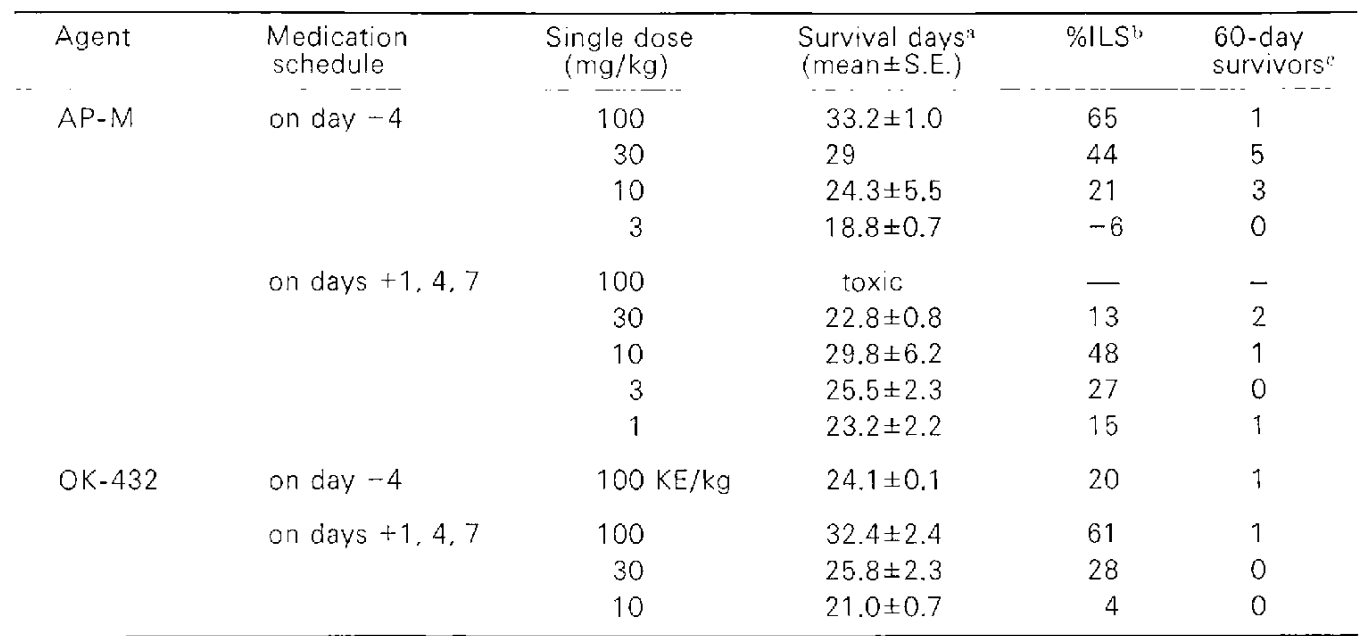

Six $\mathrm{C} 3 \mathrm{H} / \mathrm{He}$ mice were i.p. inoculated with $5 \times 10^{5}$ cells on day 0 and were i.p. administered with AP-M or OK-432 once a day according to the indicated schedule. The mean survival time of non-treated control mice was 20.1 days. a Excluding 60-day survivors. b Described in footnote ${ }^{b}$ of Table 1. Macroscopic tumor findings were negative.

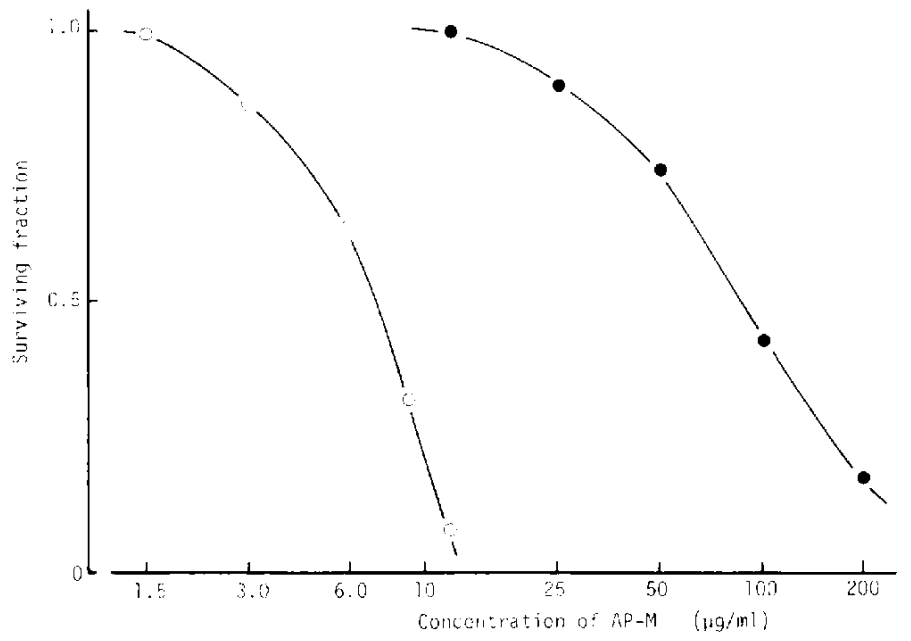

Fig. 2. Direct cytotoxic activity of AP-M against MM-2 cells. Cells $\left(2 \times 10^{5}\right.$ cells $\left./ \mathrm{ml}\right)$ were treated with graded concentrations of AP-M in the absence (O) or in the presence (O) of $10 \%$ fetal calf serum for $2 \mathrm{hr}$. The treated cells were incubated for $48 \mathrm{hr}$ and the viable cells number was determined. Data are the means of triplicate determinations.

+7. OK-432 was administered according to the same schedules in the case of AP-M. AP.M was also effective on the tumor, and the activity was similar or higher than that of OK-432. Additionally, the activity of AP-M was more potent in the premedication than in the postmedication, similar to its action against other tumor strains.

Direct cytotoxic activity of AP-M against MM-2 cells in vitro: Figure 2 shows the results of the experiments on the direct cytotoxic activity of AP-M against $\mathrm{MM}-2$ cells. MM-2 cells $\left(2 \times 10^{5}\right.$ cells $\left./ \mathrm{ml}\right)$ were treated with AP-M for $2 \mathrm{hr}$ in the presence 
or absence of fetal calf serum. The IC50 of AP-M in the absence of serum was $7.3 \mathrm{~kg} /$ $\mathrm{ml}$, but the cytotoxicity was significantly decreased by addition of serum in the reaction mixture, and the 1 C50 was $88.0 \mathrm{\mu g} / \mathrm{ml}$.

Influence of AP-M on the number and the cell population of peripheral WBC: $\mathrm{C} 3 \mathrm{H} / \mathrm{He}$ mice were i.p. administered AP-M $(100 \mathrm{mg} /$ $\mathrm{kg})$. The total number of WBC was significantly increased 2 to 5 days after the injection of AP-M. In the cell population. the percentage of lymphocytes was markedly higher and that of monocytes and basophils was also increased. After 11 days, the total cell number was similar to that of nontreated mice, but the percentage of lymphocytes was still high (Fig. 3).

Increase of PEC by AP-M and cytotoxic activity of adherent PEC: $\mathrm{C} 3 \mathrm{H} / \mathrm{He}$ mice were i.p. administered AP-M once, 4 days before

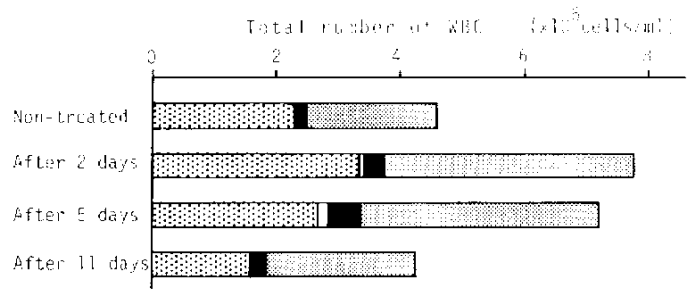

Fig. 3. Hematological findings in mice treated with AP-M. Five $\mathrm{C} 3 \mathrm{H} / \mathrm{He}$ mice in a group were i.p. administered with AP-M $(100 \mathrm{mg} / \mathrm{kg})$; and after the indicated days, the number and population of WBC in peripheral blood were determined. Data are the means of 5 mice. Neutrophils: monocytes: - Iymphocytes: the experiment. The number of PEC was markedly increased by the injection of AP-M; and when the extract was given to the mice at a dose of 30 to $100 \mathrm{mg} / \mathrm{kg}$. the number was increased to about 5 - to 6 -fold that of nontreated mice. Furthermore, PECs having the property to adhere on a plastic dish seemed to be macrophages possessing a cytotoxic activity against $\mathrm{MM}-2$ cells ( $\mathrm{Fig}$. 4 ).

Induction of ${ }^{3} \mathrm{H}-\mathrm{TdR}$ uptake capacity of spleen cells by AP-M: The spleens of the mice 4 days after the i.p. injection with AP-M were enlarged and the weight was increased. The spleen cells from the treated mice possessed a strong capacity to uptake ${ }^{3} \mathrm{H}$ TdR. while the cells from non-treated mice hardly did (Table 6). On the other hand, AP-M did not show direct migration activity against spleen cells from non-treated mice. Mitogens used in this study, however. induced the cells to have ${ }^{3} \mathrm{H}-\mathrm{TdR}$ uptake capacity (Table 7).

\section{Discussion}

Agrimonia pilosa had been known traditionally as a plant possessing an antitumor effect (3). However, we have seen only a few reports on the direct cytotoxic activity of certain extracts of this plant against tumor cells in an in vitro or an in vitro-in vivo test $(5,6)$. This work demonstrated the antitumor activity of the methanol extract from roots of Agrimonia pilosa LEDEB. (AP-M) against murine allogenic and syngeneic tumors in vivo. An important characteristic of the antitumor activity of AP-M was that

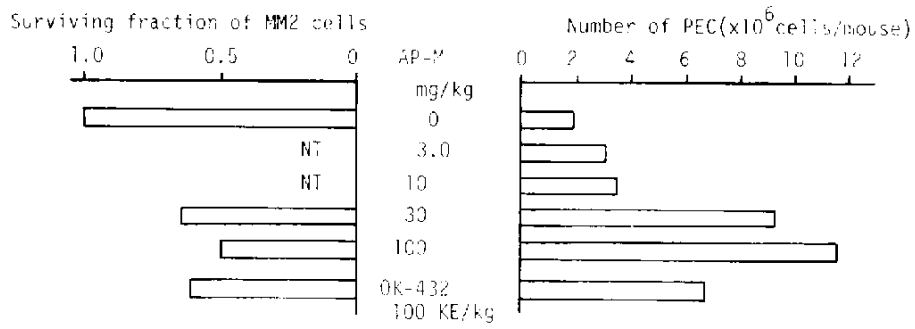

Fig. 4. Change of number of PEC in mice treated with $A P-M$ and cytotoxicity of the adherent PEC on MM-2 cells. Five $\mathrm{C} 3 \mathrm{H} / \mathrm{He}$ mice in a group were i.p. administered 4 days before the experiments with the indicated doses of AP-M or OK-432. See details in "Materials and Methods". Data for the number of PEC are the means of 5 mice. Data of the cytotoxicity test of adherent PEC are the means of triplicate determinations. NT: not tested. 
Table 6. Change of spleen weight and ${ }^{3} \mathrm{H}-\mathrm{TdR}$ uptake activity of the spleen cells from mice treated with AP-M

\begin{tabular}{|c|c|c|c|c|c|}
\hline \multirow[t]{2}{*}{ Agent } & \multirow{2}{*}{$\begin{array}{c}\text { Dose } \\
(\mathrm{mg} / \mathrm{kg})\end{array}$} & \multicolumn{2}{|c|}{ Wet weight } & \multicolumn{2}{|c|}{${ }^{3} \mathrm{H}-\mathrm{TdR}$ uptake } \\
\hline & & $\begin{array}{c}(\mathrm{mg}) \\
(\operatorname{mean} \pm S . E .)\end{array}$ & $\begin{array}{l}\% \text { of } \\
\text { control }\end{array}$ & $\begin{array}{l}\left(\times 10^{4} \mathrm{cpm}\right) \\
(\text { mean } \pm \mathrm{S} . \mathrm{E} .)\end{array}$ & $\begin{array}{l}\% \text { of } \\
\text { control }\end{array}$ \\
\hline$A P-M$ & $\begin{array}{r}100 \\
30 \\
10 \\
3\end{array}$ & $\begin{array}{c}114.5 \pm 4.1 \\
167.0 \pm 10.8 \\
91.5 \pm 6.1 \\
92.5 \pm 2.5\end{array}$ & $\begin{array}{l}138 \\
202 \\
111 \\
112\end{array}$ & $\begin{array}{r}9.52 \pm 0.32 \\
16.50 \pm 0.79 \\
5.41 \pm 0.16 \\
5.35 \pm 0.63\end{array}$ & $\begin{array}{l}262 \\
453 \\
149 \\
147\end{array}$ \\
\hline OK-432 & 100 & $114.0 \pm 4.8$ & 138 & $8.67 \pm 0.13$ & 238 \\
\hline Control & & $82.8 \pm 2.5$ & 100 & $3.64 \pm 0.07$ & 100 \\
\hline
\end{tabular}

Four $\mathrm{C} 3 \mathrm{H} / \mathrm{He}$ mice were i.p. administered with an agent 4 days before the experiments. Spleenswere weighed, and a single spleen cell suspension was prepared. Cells $\left(1 \times 10^{6}\right)$ were incubated with $1.0 \mu \mathrm{Ci}$ ${ }^{3} \mathrm{H}-\mathrm{TdR}$ for $24 \mathrm{hr}$. Experiments were carried out in triplicate for each spleen.

Table 7. Stimulation of spleen cells from non-treated mice

\begin{tabular}{lccc}
\hline Agent & Concentration & \multicolumn{2}{c}{${ }^{3} \mathrm{H}-\mathrm{TdR}$ uptake } \\
& $(\mu \mathrm{g} / \mathrm{ml})$ & $\left(\times 10^{4} \mathrm{cpm}\right)$ & $\%$ of \\
control & $($ mean $\pm \mathrm{S} . \mathrm{E})$. & 150 \\
AP-M & 50 & $1.37 \pm 0.05$ & 92 \\
& 10 & $0.84 \pm 0.05$ & 102 \\
& 3 & $0.93 \pm 0.06$ & 173 \\
KO3 LPS & 1 & $1.57 \pm 1.78$ & 668 \\
& 50 & $6.09 \pm 0.09$ & 388 \\
& 10 & $3.54 \pm 0.04$ & 304 \\
ConA & 1 & $2.77 \pm 0.06$ & 247 \\
& 50 & $2.26 \pm 0.04$ & 132 \\
& 10 & $1.20 \pm 0.02$ & 3039 \\
& 3 & $27.71 \pm 1.45$ & 1919 \\
Control & 1 & $17.50 \pm 1.69$ & 492 \\
& & $4.49 \pm 0.29$ & 100 \\
\hline
\end{tabular}

Single cell suspension was prepared from the spleen of a normal $\mathrm{C} 3 \mathrm{H} / \mathrm{He}$ mouse. Cells $\left(1 \times 10^{6}\right)$ were incubated with each agent for $24 \mathrm{hr}$ and were further incubated with $1.0 \mu \mathrm{Ci}{ }^{3} \mathrm{H}$-TdR for $24 \mathrm{hr}$. Experiments were carried out in triplicate.

premedication of this agent was more effective than its postmedication. When AP$M$ was i.p. administered 4 days before the i.p. inoculation of S-180 cells, the activity seemed to be highest; and even in the case of injection 14 days before the cell inoculation, the extract significantly prolonged the life span of the mice. AP-M showed similar or higher activity than OK-432 against MM-2 mammary carcinoma in the same medication schedule.

A streptococcal preparation, OK-432, is known to have effective antitumor and immune modulatory activities in experimental animals $(8-10)$. So, we performed comparative investigations on the activities of AP-M and OK-432 against lymphocytes and macrophages in mice, which are considered to be involved in the immune responses. Total peripheral WBC number was increased from 2 to 5 days after i.p. injection of AP-M, and especially. lymphocytes and monocytes were increased. Moreover, when AP-M or OK-432 was i.p. injected into mice before 4 days, the number of PEC and the weight of the spleen were significantly increased; and 
the PECs and the spleen cells possessed capacities of cytotoxic and self-growing activities, respectively. These activities induced by 30 to $100 \mathrm{mg} / \mathrm{kg}$ of AP-M were similar or higher than those by $100 \mathrm{KE} / \mathrm{kg}$ of OK-432. AP-M did not show direct migration activity against spleen cells from non-treated mice. On the other hand, the antitumor activity of AP-M on S-180 ascites type tumor-bearing mice was markedly minimized or abolished by the pretreatment of CPA.

From these results, it is thought that the antitumor activity of the methanol extract of Agrimonia pilosa LEDEB. may be provided by host-mediated actions so that the extract stimulates macrophages and induces cytotoxic macrophages and the stimulated macrophages activate immune charging and cytotoxic lymphocytes.

Agrimonia pilosa is rich in tannin (11) which generally shows potent astringent action, and most of the effects of this plant on diseases are believed to be based on this constituent. However, it is difficult to explain the antitumor activity of AP-M from only the direct cytotoxic activity because if the effective constituent is tannin, it seems that it would rapidly bind to many components in the host animal. In fact, the direct cytotoxicity of AP-M was quite substantial, but was diminished to about one-tenth by the addition of calf serum to the culture. However. we cannot deny the possibility that tannin contained in this plant may act as an antitumor constituent. Further studies on the isolation of the effective constituents from this plant and on mechanisms related to the antitumor activity are in progress.

\section{References}

1 Akamatsu, K.: Shinteiwakanyaku. p. 378, Ishiyakushuppan. Tokyo (1970) (in Japanese)

2 Chiang Su New Medical College: Dictionary of Chinese Crude Drugs. p. 665, Shanghai Scientific
Technologic Publisher, Shanghai (1977) (in Chinese)

3 Li,S. Z.: Sekidasen. In Shinchukotei KokuyakuHonzokomoku, Edited by Kimura, K., Vol. 13 , p. 389-392. Shunyodoshoten. Tokyo (1974) (in Japanese)

4 Sugi, M.: Cancer therapy by Chinese crude drugs. In Cancer Therapy in China Today. Edited by Kondo, K., p. 95-96. Shizensha, Tokyo (1977) (in Japanese)

5 Koshiura, R., Miyamoto, K., Takada, Y. and Kiriyama, N.: Studies on the constituents of Agrimonia pilosa LEDEB. I. Biological activities of the acidic fraction soluble in $n$-hexane of the roots. Yakugaku Zasshi 100, 1167-1170 (1980) (Abs. in English)

6 Sato, A.: Antitumor activity of some crude drugs (XII). Antitumor activity of Agrimonia pilosa Ledeb. (II). Proc. Japan. Cancer Assoc. (43ro) 280 (1984) (in Japanese)

7 Ohta, M., Mori, M., Hasegawa, T., Nagase, F., Nakashima, I., Naito, S. and Kato, N.: Further studies of the polysaccharide of Klebsiella possessing strong adiuvanticity. I. Production of the adjuvant polysaccharide by noncapsulated mutant. Microbiol. I mmunol. 25, 939-948 (1981)

8 Okamoto, H., Shoin, S. and Koshimura, S. Streptolysin S-forming and antitumor activities of group A streptococci. In Bacterial Toxins and Cell Membranes, Edited by Jeljaszewicz, J. and Wadstrom. T., p. 259-289, Academic Press Inc. New York (1978)

9 Kai, S., Tanaka, J., Nomoto, K. and Torisu, M.: Studies on the immunopotentiating effects of a streptococcal preparation. OK-432. I. Enhancement of $T$ cell-mediated immune responses of mice. Clin. Exp. Immunol. 37, 98-105 (1979)

10 Murayama, T., Natsuume-Sakai, S., Ryoyama, K. and Koshimura, S.: Studies on the properties of a streptococcal preparation, OK-432 (NSCB116209), as an immunopotentiator. II. Mechanism of macrophage activation by OK-432. Cancer Immunol. Immunother. 12, 141-146 (1982)

11 Higashi, J., Mizobuchi, K., Nagoshi, K. and Nakai, T.: Pharmacognostical studies on "Ryuuge-soo". Shoyakugaku Zasshi 10, 29-33 (1956) (in Japanese) 